\title{
BRPKM
}

Buletin Riset Psikologi dan Kesehatan Mental

http://e-journal.unair.ac.id/index.php/BRPKM

e-ISSN: 2776-1851

ARTIKEL PENELITIAN

\section{Hubungan antara Perilaku Prososial dengan Kesejahteraan Psikologis pada Penerima Beasiswa Bidikmisi}

\author{
DURROTUN NASIHAH \& ILHAM NUR ALFIAN*
}

Fakultas Psikologi Universitas Airlangga

\begin{abstract}
ABSTRAK
Penelitian ini bertujuan untuk mengetahui hubungan antara perilaku prososial dengan kesejahteraan psikologis pada mahasiswa bidikmisi. Perilaku prososial adalah perilaku yang bertujuan menguntungkan dan bermanfaat bagi orang lain tanpa memandang siapa orang lain tersebut. Kesejahteraan psikologis adalah istilah untuk menggambarkan kesehatan psikologis individu ketika fungsi psikologisnya positif. Penelitian dilakukan pada 246 mahasiswa penerima beasiswa bidikmisi yang berusia 18-21 tahun. Pengumpulan data dilakukan menggunakan kuesioner skala Prosocial Tendencies Measure (PTM) yang terdiri dari 23 aitem dan Ryff's Scales of Psychological Well-Being (RSPWB) yang terdiri dari 21 aitem. Teknik analisis data dilakukan menggunakan korelasi Pearson menggunakan perangkat lunak IBM SPSS 25.0 for Windows. Hasil penelitian ini menunjukkan jika terdapat hubungan antara perilaku prososial aspek altruism dan aspek menolong terhadap kesejahteraan psikologis mahasiswa penerima beasiswa bidikmisi, dan tidak terdapat hubungan antara perilaku prososial dalam aspek emosional, publik, dan krisis terhadap kesejahteraan psikologis mahasiswa penerima beasiswa bidikmisi.
\end{abstract}

Kata kunci: kesejahteraan psikologis, mahasiswa bidikmisi, perilaku prososial

\begin{abstract}
This study aims to determine about the relationship between prosocial behavior and psychological wellbeing in bidikmisi students. Prosocial behavior is behavior that aims to benefit others and regardless of who the other person is. Psychological well-being is a term to describe an individual's psychological health when their psychological functioning is positive. This research was conducted on 246 bidikmisi's students aged 18-21. Data collection was carried out using a Prosocial Tendencies Measure (PTM) scale consisting of 23 items and Ryff's Scales of Psychological Well-Being (RSPWB) consisting of 21 items. The data analysis technique was performed using pearson's correlation using IBM SPSS 25.0 for Windows. The results showed that there was a relationship between altruistic prosocial behaviors and compliant prosocial behaviors to psychological well-being of bidikmisi students, and there is no relationship between emotional prosocial behaviors, public prosocial behaviors, and crisis prosocial behaviors to psychological well-being of bidikmisi student.
\end{abstract}

Keywords: bidikmisi student, prosocial behavior, psychological well-being 
Buletin Penelitian Psikologi dan Kesehatan Mental (BRPKM), 2021, Vol. 1(1), 852-858

*Alamat korespondensi: Fakultas Psikologi Universitas Airlangga, Kampus B Universitas Airlangga Jalan

Airlangga 4-6 Surabaya 60286. Surel: ilham.nuralfian@psikologi.unair.ac.id

Naskah ini merupakan naskah dengan akses terbuka dibawah ketentuan the Creative Common Attribution License (CC-BY-4.0) (http://creativecommons.org/licenses/by/4.0), sehingga penggunaan, distribusi, reproduksi dalam media apapun atas artikel ini tidak dibatasi, selama sumber aslinya disitir dengan baik.

\section{PENDAHULUAN}

Di Indonesia kemiskinan masih menjadi masalah pokok, karena itulah tidak semua masyarakat memperoleh pendidikan yang layak. Untuk mengatasi hal ini, pemerintah memberikan bantuan beasiswa kepada mahasiswa yang memiliki potensi akademik yang bagus tetapi kurang mampu secara ekonomi, program ini disebut beasiswa bidikmisi (Rohmah \& E. N., 2015). Penerima beasiswa bidikmisi memiliki ketentuan, yaitu harus memiliki potensi akademik yang unggul, keterbatasan dalam hal ekonomi, lulus seleksi perguruan tinggi. Jika sudah memenuhi ketentuan dan menerima beasiswa, maka penerima beasiswa harus mengikuti aturan yang diberikan oleh universitas. Aturan ini cukup membuat mahasiswa penerima beasiswa cemas karena harus menyelesaikan kuliah selama 8 semester, IPK tidak boleh turun, dan IPK harus diatas 2,75. Jika aturan tersebut tidak dipatuhi maka beasiswa akan diberhentikan, untuk mahasiswa yang benar-benar hidup dari uang beasiswa tentu hal ini sangat dihindari.

Dari hasil survei yang dilakukan oleh peneliti pada tanggal 16-18 Maret 2021 terhadap beberapa penerima beasiswa bidikmisi menunjukkan jika uang beasiswa tidak cukup untuk memenuhi kebutuhan selama berkuliah, untuk menutupi hal tersebut mereka meminta uang kepada orang tua (bagi yang orang tuanya mampu), ada juga mahasiswa yang berjualan online shop, dan bekerja part-time untuk memenuhi kebutuhan, sehingga perlu pembagian waktu yang baik untuk kuliah dan bekerja. Selain itu, ada mahasiswa yang menggunakan uang beasiswa untuk membantu perekonomian keluarganya dan pada akhirnya uang beasiswa tersebut digunakan untuk kepentingan pribadi di luar kebutuhan kuliah. Hal lain yang dialami oleh mahasiswa bidikmisi adalah adanya pihak yang mengatakan jika penerima beasiswa bidikmisi suka berfoya-foya padahal tidak semua penerima beasiswa melakukan hal tersebut, ada mahasiswa yang benar-benar membutuhkan beasiswa tersebut untuk bisa berkuliah. Beberapa mahasiswa juga merasa tidak percaya diri ketika berada di kelas sehingga kurang leluasa selama proses pembelajaran perkuliahan.

Berdasarkan permasalahan yang dialami di atas, mahasiswa bidikmisi cenderung mengalami masalah baik internal maupun eksternal yang mampu memengaruhi kesejahteraan psikologis yang dimiliki. Kesejahteraan psikologis ialah istilah yang digunakan dalam menggambarkan kesehatan psikologis individu yang didasarkan pada pemenuhan kriteria fungsi psikologi positif (Ryff \& Keyes, 1995). Aspekaspek yang terdapat di dalam kesejahteraan psikologis antara lain: ketika individu menerima diri, hal baik maupun hal buruk (self-acceptance), kemampuan individu dalam berhubungan dengan orang lain (positive relation with others), kemampuan individu untuk menentukan keputusan sendiri secara mandiri (autonomy), kemampuan penguasaan lingkungan (environmental mastery), memiliki tujuan hidup yang tinggi dan terarah (purpose in life), rasa ingin mengembangkan diri dan terbuka terhadap pengalaman baru (personal growth) (Ryff, 1989). 
Diener mengatakan jika kondisi sosial ekonomi memengaruhi kesejahteraan psikologis (Wells, 2010). Haan, Kaplan dan Syme juga menjelaskan jika kesuksesan dan kegagalan finansial mempengaruhi pencapaian, penguasaan lingkungan, dan penerimaan diri seseorang (Wells, 2010). Kondisi sosial ekonomi juga merupakan salah satu faktor kesejahteraan psikologis, kesejahteraan psikologis akan terancam ketika emosi negatif yang ekstrem berlangsung sangat lama sehingga memengaruhi kemampuan seseorang untuk berfungsi dalam kehidupannya sehari-hari (Huppert, 2009).

Heiman dan Kariv menjelaskan jika kesejahteraan psikologis yang rendah berdampak pada kognitif, emosi, perilaku, dan fisiologis. Efek emosional yang dialami bisa frustasi, sedih, cemas, marah, dan sulit memotivasi diri (Safaria, T., 2012). Sementara efek fisiologisnya adalah daya tahan tubuh menurun, badan lesu, pusing, dan kesulitan untuk tidur pulas. Karena itulah kesejahteraan psikologis sangat penting untuk individu supaya bisa menjalani efektivitas dalam berbagai bidang kehidupan, salah satunya adalah bidang akademik. Hal-hal positif seperti kebahagiaan dan kepuasan berpengaruh dalam membentuk kondisi psikologis yang positif sehingga membentuk kesejahteraan psikologis seseorang (Ryff \& Keyes, 1995).

Perilaku prososial merupakan salah satu perilaku positif, perilaku prososial diharapkan bisa membantu mahasiswa mengembangkan pertumbuhan dirinya, sesuai dengan yang dikatakan Ryff jika pertumbuhan pribadi (personal growth) merupakan salah satu aspek dari kesejahteraan psikologis (Ryff \& Keyes, 1995). Menurut Carlo dan Randall (2002) aspek perilaku prososial terdiri dari altruism, yaitu bantuan secara sukarela yang diberikan karena mengutamakan kesejahteraan orang lain, menolong (compliant) yaitu membantu orang lain ketika orang lain meminta pertolongan baik secara verbal maupun non-verbal, emosional (emotional) yaitu membantu orang lain ketika keadaan emosional, publik (public) yaitu menolong orang lain yang dilakukan di depan banyak orang untuk mendapatkan pengakuan dari orang lain, anonim (anonymous) membantu orang lain tanpa diketahui, krisis (dire) membantu orang lain ketika orang lain dalam keadaan darurat.

Hasil penelitian yang dilakukan oleh Piliavin (dalam Kumar, 2015) menunjukkan jika perilaku prososial merupakan salah satu faktor penting dalam mengembangkan kesejahteraan psikologis. Sears, dkk. (1999) mengatakan jika perilaku prososial memberikan kepuasan dan perasaan yang lebih baik daripada sebelum menolong, selain itu perilaku prososial juga memperbaiki perasaan orang yang menolong. Salah satu faktor yang memengaruhi perilaku prososial adalah distress diri dan rasa empatik. Distress diri (personal distress) merupakan reaksi pribadi diri individu terhadap penderitaan orang lain, seperti cemas, takut, prihatin, tidak berdaya, atau perasaan apapun yang dialaminya. Rasa empatik (empathic concern) ialah perasaan simpati dan perhatian terhadap orang lain, khususnya untuk berbagi pengalaman atau secara tidak langsung merasakan penderitaan orang lain. Yang membedakan keduanya adalah penderitaan diri terfokus pada diri sendiri, sedangkan rasa empatik terfokus kepada korban. Hubungan antara keduanya adalah ketika individu mengalami tekanan atau distress terhadap diri sendiri, maka individu akan berusaha untuk mengurangi rasa kegelisahan dengan cara membantu orang lain yang membutuhkan, hal ini merupakan bentuk dari rasa empatik.

Berdasarkan permasalahan yang dialami oleh mahasiswa penerima beasiswa bidikmisi, baik internal maupun eksternal, Universitas Airlangga harus memperhatikan kesejahteraan psikologis yang dimiliki oleh mahasiswa penerima beasiswa bidikmisi supaya mereka bisa maksimal dan tidak terganggu dalam proses pembelajaran. Mengingat penerima beasiswa bidikmisi yang dibina oleh Universitas Airlangga meningkat setiap tahun. 


\section{Desain Penelitian}

\section{METODE}

Desain penelitian ini menggunakan tipe pendekatan kuantitatif-survei. Penulis menggunakan tipe kuantitatif dengan tujuan memindahkan ide-ide abstrak secara deduktif ke teknik pengumpulan data yang lebih spesifik. Sedangkan teknik survei sendiri adalah teknik dimana subjek penelitian menjawab pertanyaan yang berhubungan dengan opini, kepercayaan, karakteristik, dan perilaku yang telah dilakukan dimasa lalu maupun sekarang. Data dikumpulkan menggunakan kuesioner yang berbentuk online dan disebarkan menggunakan google form. Skala yang digunakan dalam penelitian ini adalah Prosocial Tendencies Measure (PTM) milik Carlo dan Randall (2002) untuk mengukur perilaku prososial dan Ryff's Scales of Psychological Well-Being (RSPWB) milik Ryff (1989) yang digunakan untuk mengukur kesejahteraan psikologis. Uji validitas menggunakan metode content validity index dan pengukuran reliabilitas menggunakan koefisien Alpha Cronbach. Analisis data menggunakan korelasi Pearson dengan bantuan program IBM SPSS 25.0 for Windows. Analisis ini digunakan untuk mengetahui hubungan antara perilaku prososial dengan kesejahteraan psikologis pada mahasiswa penerima beasiswa bidikmisi di Universitas Airlangga.

\section{Partisipan}

Partisipan dalam penelitian ini adalah mahasiswa aktif Universitas Airlangga yang menerima beasiswa bidikmisi. Teknik sampling yang digunakan dalam penelitian ini ialah purposive sampling. Dalam menentukan jumlah minimal sampel dalam penelitian ini, penulis menggunakan rumus slovin dan memperoleh hasil sampel minimal 100 partisipan. Sebelum mengisi kuesioner, para partisipan menyetujui untuk berpartisipasi melalui informed consent yang diberikan secara online bersamaan dengan kuesioner yang diberikan. Jumlah partisipan dalam penleitian ini 246 mulai dari usia 18 sampai 19 tahun.

\section{Pengukuran}

Perilaku prososial dalam penelitian ini diukur menggunakan Prosocial Tendencies Measure (PTM) milik Carlo dan Randall (2002) yang telah digunakan oleh Jati Tesih Pinanggit (2018). Skala ini terdiri dari 23 aitem, yaitu 22 aitem favorable dan 1 aitem unfavorable dengan 5 kategori jawaban (1="sama sekali tidak mirip saya", 5="sangat mirip saya"). Kesejahteraan psikologis diukur menggunakan Ryff's Scales of Psychological Well-Being (RSPWB) milik Ryff (1989) yang digunakan oleh Pinanggit (2018). Skala ini memiliki 21 aitem, yaitu 2 aitem favorable dan 19 aitem unfavorable dengan 4 kategori jawaban (1="sangat tidak sesuai", 4="sangat sesuai").

Validitas yang digunakan dalam penelitian ini adalah metode content validity index, penggunaan metode ini dinilai oleh 3 orang yang berkualifikasi sebagai ilmuwan psikologi dan masyarakat awam. Skala perilaku prososial pada penelitian ini memiliki validitas 0,979 dan skala kesejahteraan psikologis pada penelitian ini memiliki validitas 0,994, semakin mendekati angka 1, maka skala yang digunakan memiliki tingkat validitas yang baik. Sedangkan hasil pengukuran reliabilitas pada skala perilaku prososial sebesar 0,761 dan reliabilitas pada skala kesejahteraan psikologis sebesar 0,855.

Uji asumsi yang dilakukan adalah uji normalitas untuk mengetahui apakah data berdistribusi normal atau tidak. Uji normalitas menggunakan teknik Kolmogrov-smirnov dan menunjukkan nilai sebesar 0,200 . 


\section{HASIL PENELITIAN}

Hasil analisis deskriptif menunjukkan jika partisipan pada penelitian ini memiliki kesejahteraan psikologis rendah sebanyak 127 responden $(51,6 \%)$, sedang sebanyak 11 responden $(4,5 \%)$, dan tinggi sebanyak 108 responden (43,9\%).

Hasil analisis korelasi diketahui jika perilaku prososial pada aspek altruism berkorelasi positif $(r(246)=0,172)$ dengan kesejahteraan psikologis, Perilaku prososial pada aspek menolong berkorelasi positif $(r(246)=0,167)$ dengan kesejahteraan psikologis.

\section{DISKUSI}

Berdasarkan analisis yang telah dilakukan, diperoleh hasil jika terdapat hubungan yang positif antara dua aspek perilaku prososial dengan kesejahteraan psikologis, yaitu aspek altruisme dan menolong. Altruisme adalah bantuan yang dilakukan secara sukarela yang terjadi karena rasa peduli terhadap kesejahteraan dan kebutuhan orang lain. Hal ini menunjukkan jika semakin tinggi perilaku prososial pada aspek altruisme, maka semakin tinggi pula kesejahteraan psikologis yang dimiliki oleh mahasiswa penerima beasiswa bidikmisi. Sejalan dengan hasil penelitian Megawati dan Herdiyanto (2016) yang mengatakan jika perilaku prososial pada aspek altruisme berdampak terhadap kesejahteraan psikologis. Lebih tepatnya, hal ini memiliki dampak terhadap kesejahteraan psikologis dimensi berhubungan positif dengan orang lain (positive relation with others).

Aspek menolong (compliant) dalam perilaku prososial adalah membantu orang lain ketika orang lain meminta pertolongan, baik secara verbal maupun non-verbal. Bantuan ini diberikan secara langsung kepada orang yang meminta bantuan tanpa berpikir panjang mengenai manfaat dan kerugian. Hubungan variabel kesejahteraan psikologis dengan dimensi menolong merupakan hubungan yang positif dan signifikan, hal ini mengartikan jika semakin tinggi perilaku prososial pada aspek menolong maka akan diikuti dengan peningkatan nilai pada kesejahteraan psikologis. Sejalan dengan hasil penelitian Kumar (2015) yang menyatakan tindakan menolong pada perilaku prososial memberikan pengaruh positif pada kesejahteraan psikologis.

Dari hasil penelitian ini juga terdapat aspek dari perilaku prososial yang tidak berhubungan dengan kesejahteraan psikologis, yaitu aspek emosional. Aspek emosional adalah membantu orang lain disebabkan oleh perasaan emosi berdasarkan situasi yang terjadi. Artinya, individu yang sering melakukan perilaku prososial dilandasi oleh aspek emosional memiliki kesejahteraan psikologis yang baik, namun bisa juga memiliki kesejahteraan psikologis yang buruk. Selaras dengan hal ini, aspek krisis (dire) dari perilaku prososial yang memiliki arti menolong orang yang sedang dalam keadaan darurat, juga tidak berhubungan dengan kesejahteraan psikologis. Jika ditarik garis keduanya memiliki kesamaan, yaitu menolong orang lain ketika situasi genting. Individu cenderung tidak memberikan bantuan dalam situasi genting karena beberapa faktor, yaitu kehadiran orang lain, sifat lingkungan, fisik, dan tekanan keterbatasan waktu (Sears dkk.., 1999). Carlo dan Randall (2002) juga mengatakan jika hubungan yang dimiliki dengan orang lain yang sedang membutuhkan pertolongan juga memengaruhi aspek emosional tersebut, sehingga jika orang yang membutuhkan pertolongan adalah orang yang dikenal maka kecenderungan untuk menolong lebih besar dan begitupun sebaliknya, jika orang yang membutuhkan pertolongan. Aspek anonim (menolong tanpa sepengatuhan orang yang ditolong) dalam perilaku prososial juga tidak berhubungan dengan kesejahteraan psikologis. Hal ini menunjukkan jika individu sering melakukan perilaku prososial dilandasi aspek anonim, individu memiliki kesejahteraan psikologis yang baik, namun bisa juga memiliki kesejahteraan psikologis yang buruk. 
Carlo dan Randall (2002) mengatakan jika mobilitas sosial meningkatkan dewasa awal untuk membantu orang lain tanpa memperlihatkan siapa diri mereka. Aspek publik (menolong orang lain yang sengaja dilakukan di depan orang-orang untuk memperoleh pengakuan dan rasa hormat serta meningkatkan harga diri) dalam perilaku prososial juga tidak berhubungan dengan kesejahteraan psikologis, ini berarti jika responden tidak memerlukan pengakuan dan mencari simpati orang disekitarnya untuk memberikan pertolongan. Menurut Sears dkk. (1999) kehadiran orang lain dapat menghambat usaha untuk memberikan pertolongan, karena kehadiran orang yang begitu banyak menyebabkan terjadinya penyebaran tanggung jawab.

\section{SIMPULAN}

Berdasarkan analisis yang telah dilakukan, dapat disimpulkan jika terdapat hubungan signifikan, namun hanya pada dua aspek perilaku prososial, yaitu aspek altruism dan aspek menolong, hasil yang tidak signifikan terdapat pada aspek emosional, publik, anonim dan dire.

Hubungan dengan dua aspek perilaku prososial tersebut bersifat positif sehingga dapat disimpulkan jika semakin tinggi aspek altruism dan aspek menolong maka semakin tinggi pula kesejahteraan psikologis yang dimiliki mahasiswa penerima beasiswa bidikmisi di Universitas Airlangga. Pada penelitian ini menunjukkan tidak ada hubungan antara aspek emosional, publik, anonim dan krisis dengan kesejahteraan psikologis mahasiswa penerima beasiswa bidikmisi di Universitas Airlangga.

Penelitian selanjutnya disarankan lebih detail memperhatikan variabel yang akan diteliti, bisa juga meneliti faktor lain yang memengaruhi kesejahteraan psikologis, seperti dukungan sosial, suasana hati, pola asuh, dan lain-lain.

\section{UCAPAN TERIMAKASIH}

Penulis mengucapkan terima kasih kepada mahasiswa penerima beasiswa bidikmisi di Universitas Airlangga selaku partisipan dalam penelitian ini karena telah bersedia untuk berpartisipasi dalam penelitian ini.

\section{DEKLARASI POTENSI TERJADINYA KONFLIK KEPENTINGAN}

Durrotun Nasihah dan Ilham Nur Alfian tidak bekerja, menjadi konsultan, memiliki saham, atau menerima dana dari perusahaan atau organisasi manapun yang mungkin akan mengambil untung dari diterbitkannya naskah ini.

\section{PUSTAKA ACUAN}

Carlo, G., \& Randall, B. A. (2002). The Development of a Measure of Prosocial Behaviors for Late Adolescents. Journal of Youth and Adolescence, 31(1), 31-44. https://doi.org/10.1023/A:1014033032440 
E. H., M. (2016). Hubungan Antara Perilaku Prososial dengan Psychological Well-being pada Remaja. 132141.

Huppert, F. A. (2009). Psychological Well-being: Evidence Regarding its Causes and Consequences. Applied Psychology: Health and Well-Being, 1(2), 137-164. https://doi.org/10.1111/j.17580854.2009.01008.x

Kumar, M. V. (2015). Adolescence psychological well-being in relation to spirituality and pro-social behaviour. 361-366.

Rohmah, L., \& E. N. (2015). Persepsi Mahasiswa Bidikmisi Universitas Diponegoro Terhadap Harapan Masa Depannya. 1-15.

Ryff, C. D. (1989). Happiness Is Everything, or Is It? Explorations on the Meaning of Psychological WellBeing. 57, 1069-1081.

Ryff, C. D., \& Keyes, C. L. M. (1995). The Structure of Psychological Well-Being Revisited. 69, 719-729.

Safaria, T. (2012). Manajemen Emosi, Sebuah Panduan Cerdas Bagaimana Mengelola Emosi Positif Dalam Hidup Anda. PT. Bumi Aksara.

Sears, D. O., Freedman, J. L., \& Peplau, L. A. (1999). Psikologi Sosial (Terjemahan) (M. Adryanto \& S. Soekrisno, Trans.). Erlangga.

Wells, I. E. (2010). Psychology of emotions, motivations and actions: Psychological well-being. New York: Nova Science Publisher, Inc, 6(9), 111334. 